\title{
AEROMAGNETIC MAP OF PART OF THE MOOSELEUK LAKE QUADRANGLE, AROOSTOOK AND PISCATAQUIS COUNTIES, MAINE
}

By

L. A. Anderson, N. W. Natof, and others

GEOPHYSICAL INVESTIGATIONS
MAP GP-373

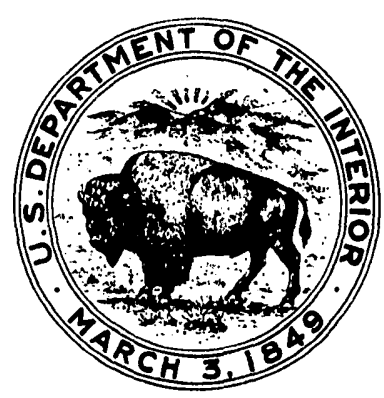

PUBLISHED BY THE U. S. GEOLOGICAL SURVEY 